\title{
Ribonucleic Acid Synthesis During Fungal Spore Germination
}

\author{
By D. W. HOLLOMON \\ CSIRO Division of Plant Industry, Canberra, A.C.T. 26or, Australia
}

(Accepted for publication 26 March 1970)

SUMMARY

Spores of several fungi were examined in an effort to understand the role of RNA in the biochemical events occurring early in germination. RNA synthesis appeared to be an essential requirement for germination in Neurospora crassa and Aspergillus nidulans but not in Alternaria solani and Peronospora tabacina. Gross changes in the relative amounts of the various molecular species of RNA were not detected during germination of $P$. tabacina and $N$. crassa spores. Pulse-labelling of the germinating spores revealed that, in $N$. crassa, ribosomal and soluble RNAs were the major species being synthesized, whereas in P. tabacina label was incorporated into soluble RNA and an unstable heterodisperse RNA, but apparently not into ribosomal RNA. This pattern of RNA synthesis in germinating $P$. tabacina spores is similar to that found in cleaving embryos of certain animals where development is also rapid and, like germinating $P$. tabacina spores, can occur when RNA synthesis is inhibited.

\section{INTRODUCTION}

Protein synthesis appears essential for the germination of fungal spores (Gottlieb, I966). However, studies with Peronospora tabacina conidia revealed that RNA synthesis, although occurring before germ-tube emergence, was not required for germination (Hollomon, 1969). Although several workers have examined RNA synthesis in germinating fungal spores (for review see Gottlieb, I966), the importance of this synthesis in the germination of species other than P. tabacina is largely unknown. The importance of this synthesis in the germination of spores of five fungi has been assessed. Results show that species differ not only in their need to synthesize RNA, but also in the types of RNA being synthesized.

\section{METHODS}

\section{Preparation and germination of spores}

Peronospora tabacina Adam. Conidia were collected and prepared as described previously (Hollomon, 1969) except that chloramphenicol (100 $\mu \mathrm{g} . / \mathrm{ml}$.) was added to the germination medium to limit bacterial contamination. (The rate of germination was unaltered by this concentration of chloramphenicol.) Conidial suspensions $\left(2 \cdot 0 \times 10^{5} / \mathrm{ml}\right.$.) were incubated at $15^{\circ}$ and germ tubes first appeared after $60 \mathrm{~min}$.

Neurospora crassa Shear and Dodge. Using cold sterile distilled water, conidia were washed from 4 day cultures grown on agar slopes of the medium described by Ryan (I950). Mycelial fragments were removed by filtration through glass wool, and when conidial suspensions $\left(\mathrm{I} \times \mathrm{I}^{6} / \mathrm{ml}\right.$.) were incubated at $30^{\circ}$ in Ryan's medium, germ tubes first appeared after 2 h.; after 8 h. $80 \%$ of the conidia had germinated. 
Aspergillus nidulans (Eidam) Wint. Using $0.02 \%(\mathrm{v} / \mathrm{v})$ Teepol, conidia were washed from 7 day cultures grown on agar slopes of Czapek-Dox medium (pH 6.8) modified by the addition of biotin (I0 $\mu \mathrm{g}$./1.) and trace element solution (Sussman, I966) $(1 \cdot 0 \mathrm{ml} . / 1$.). Suspensions were filtered to remove mycelial fragments and washed once with cold sterile distilled water. When suspensions $\left(4 \times 10^{6}\right.$ conidia $/ \mathrm{ml}$.) were incubated at $37^{\circ}$ in the modified Czapek-Dox medium, germ tubes appeared after $4 \mathrm{~h}$; ; at $8 \mathrm{~h}$. $80 \%$ of the conidia had germinated.

Alternaria solani (Ellis and Martin) Sorauer. Sporulation of this fungus is stimulated by alternating periods of light and dark (Lukens, I963). Cultures were, therefore, grown at $24^{\circ}$ on potato glucose agar and placed on a windowsill where they received natural daylight. Conidia were washed from I 4 day cultures with cold sterile distilled water and mycelial fragments removed by filtration through glass wool. Conidial suspensions $\left(2 \times \mathrm{IO}^{5} / \mathrm{ml}\right.$.) were incubated at $26^{\circ}$ in the modified Czapek-Dox medium used for Aspergillus nidulans; germ tubes first appeared after 60 min.; at 6 h. $90 \%$ of the conidia had germinated.

Puccinia graminis Pers. f. sp. tritici Eriks and E. Henn. Uredospores (strain ANZ 34-I,2,3,6,7 kindly supplied by $\operatorname{Dr}$ N.H. Luig, University of Sydney, N.S.W., Australia) were stored under vacuum in a refrigerator. To initiate germination $5 \mathrm{mg}$. of uredospores were heat-shocked for $5 \mathrm{~min}$. at $40^{\circ}$ (Bromfield, I964) and then suspended in $2.5 \mathrm{ml} .0 .01 \%(\mathrm{v} / \mathrm{v})$ Tween 20 . When shaken at $26^{\circ}$ in $50 \mathrm{ml}$. conical flasks germ tubes appeared within $30 \mathrm{~min}$.; maximum germination, which never exceeded $60 \%$, occurred after $2 \mathrm{~h}$.

Germination was considered complete when the first sign of a germ tube was noted and, unless stated otherwise, all species were germinated without shaking in $5.0 \mathrm{~cm}$. diameter Petri dishes containing a final volume of $2.5 \mathrm{ml}$. Except for the Peronospora tabacina medium, which was not sterilized, all media were autoclaved at $117^{\circ}$ for I 5 min.

RNA extraction from germinating Peronospora tabacina and Neurospora crassa conidia

Germination was stopped by cooling with ice and conidia were collected on membrane filters (Oxoid). Bentonite $(7 \cdot 0 \mathrm{mg}$.) was added and the conidia were then transferred to a chilled mortar containing solid $\mathrm{CO}_{2}$, sand, and sufficient $20 \%$ (w/v) sodium dodecyl sulphate (SDS) to give a final concentration of $\mathrm{r} \%(\mathrm{w} / \mathrm{v}) \mathrm{SDS}$. Conidia were broken by grinding (microscopic examination showed breakage always exceeded $80 \%$ ) and extracted with $3.0 \mathrm{ml} .0 .05 \mathrm{M}$-tris $+\mathrm{HCl}(\mathrm{pH} 8 \cdot 0)$ containing $5.0 \mathrm{mM}^{\circ} \mathrm{MgCl}_{2}$. The broken spore suspension was extracted three times with tris-saturated phenol containing $0.05 \mathrm{M}$-EDTA and $0.5 \%(\mathrm{w} / \mathrm{v})$ SDS, the first phenol extraction being carried out by shaking for $3 \mathrm{~min}$. at $60^{\circ}$. Subsequent phenol extractions and further purification were carried out as described previously (Hollomon, 1969).

\section{Fractionation of $R N A$ by polyacrylamide gel electrophoresis}

Nine $\mathrm{cm}$. polyacrylamide gels $(2 \cdot 4 \% \mathrm{w} / \mathrm{v})$ were prepared in Perspex tubes (I/4 in. internal diameter $\times 5$ in. long) by the method of Loening (1967) except that $10 \%$ $(\mathrm{v} / \mathrm{v})$ glycerol and $\mathrm{I} \%(\mathrm{w} / \mathrm{v})$ agarose were added to facilitate slicing the gels. RNA samples were layered directly on to the gels in tris + acetate buffer (final concentration $0.045 \mathrm{M}$-tris $+\mathrm{HCl} ; 0.02 \mathrm{M}-\mathrm{Na}$ acetate; $2 \mathrm{~mm}$-sodium EDTA; acetic acid was used to adjust to $\mathrm{pH} 7 \cdot 3$. at $24^{\circ}$ ) containing $15 \%$ (v/v) glycerol, and electrophoresis was carried 
out for $150 \mathrm{~min}$. at $5 \mathrm{~mA} / \mathrm{gel}$ and $10 \mathrm{~V} / \mathrm{cm}$. using tris + acetate buffer containing $10 \%$ (v/v) glycerol.

After electrophoresis gels were stained in $0.025 \%(\mathrm{w} / \mathrm{v})$ Azure B in 0.065 M-citrate + phosphate buffer $\left(\mathrm{pH}_{4} \cdot 6\right)$, de-stained overnight in distilled water, and scanned in a Joyce Loebl Chromoscan with a red $(620 \mathrm{~nm}$.) filter. Under these conditions direct proportionality between absorbance and amount of nucleic acid did not exist, and therefore quantitative estimation of the RNA was not possible. After scanning, gels were frozen with solid $\mathrm{CO}_{2}$ and sliced into $\mathrm{I} \mathrm{mm}$. sections with a McIlwain gell slicer (Mickle Engineering, Gomshall, Surrey). Two sections were placed into each scintillation vial and hydrolysed with $0.5 \mathrm{ml}$. hyamine for $30 \mathrm{~min}$. at $50^{\circ}$. To accommodate the water present in the samples six drops of Triton X roo were added to each vial from a Pasteur pipette and the radioactivity was counted in a Packard Tri-carb Liquid Scintillation Spectrometer using 2,5 diphenoxazole $(6 \cdot 0 \mathrm{~g} . / 1$. toluene) as scintillant.

\section{Preparation of ribosomes from Peronospora tabacina conidia}

Germinated conidia were augmented with dormant conidia to provide sufficient material for manipulation. Conidia were collected on a membrane filter and transferred to a chilled mortar containing solid $\mathrm{CO}_{2}$, sand and $28 \mathrm{mg}$. sodium deoxycholate. Conidia were broken by grinding and upon thawing were extracted with $5.0 \mathrm{ml}$. buffer (0.0I M-tris $+\mathrm{HCl}(\mathrm{pH} 7.8) ; 0.0 \mathrm{I} \mathrm{M-Mg}$ acetate; $0.06 \mathrm{M}-\mathrm{KCl} ; 0.006 \mathrm{M}$-mercaptoethanol (KMT buffer)). Sand was sedimented from this extract by centrifugation for I min. at IOo $g$ and the supernatant fluid incubated at $37^{\circ}$ for 20 min. to permit digestion of messenger RNA. Mitochondria and larger particles were sedimented by centrifugation for $10 \mathrm{~min}$. at $10,000 \mathrm{~g}$ and the supernatant fluid further centrifuged for $2 \mathrm{~h}$. at I I 7,000 $\mathrm{g}$. The ribosomal pellet was suspended in $2.0 \mathrm{ml}$. KMT buffer and centrifuged for $90 \mathrm{~min}$. at I I 7,000 $\mathrm{g}$ to yield washed ribosomes. These ribosomes gave a characteristic u.v. spectrum with a $E_{1 \mathrm{~cm} .}^{260}: E_{1 \mathrm{~cm}}^{230}$ of $\mathrm{I}_{4} 4$, indicating the presence of about $20 \%$ contaminating protein (Peterman, 1964). Dialysis for $90 \mathrm{~min}$. against $0.05 \mathrm{M}$-tris + $\mathrm{HCl}(\mathrm{pH} \mathrm{7.8)}$ containing $0.0 \mathrm{I}$ M-sodium EDTA resulted in dissociation of the ribosomes into two subunits which could be fractionated on a 5 to $20 \%(\mathrm{w} / \mathrm{v})$ sucrose density gradient by centrifugation for $2 \mathrm{~h}$. at 37,000 rev./min. (Spinco S.W. 39 rotor).

RNA present in these ribosome preparations was fractionated by polyacrylamide gel electrophoresis using the procedure described above, except that in the gels and the electrophoresis buffer glycerol was replaced by $0.2 \%(w / v)$ SDS. Ribosomes were disrupted in KMT buffer (without mercaptoethanol) containing $0.5 \%(\mathrm{w} / \mathrm{v})$ SDS and I0 \% (w/v) sucrose and layered on the gels. After electrophoresis (I 50 min., $5 \mathrm{~mA}$ ) gel, $10 \mathrm{~V} / \mathrm{cm}$.) gels were rinsed with distilled water for $30 \mathrm{~min}$. and scanned, using; transmitted u.v. irradiation by the method of Loening (I969) (except that the $p$ dimethylaminobenzaldehyde filter was omitted). Gels were then sectioned and prepared for radioactive counting as described earlier.

Radioisotopes. Reconstituted $\left[{ }^{14} \mathrm{C}\right]$ yeast protein hydrolysate was purchased from Schwarz Biochemicals Inc., Orangeburg, N.Y., U.S.A. $\left[{ }^{3} \mathrm{H}\right]$ uridine ( $33 \mathrm{Ci} / \mathrm{m}$-mole) and $\left[{ }^{3} \mathrm{H}\right]$ cytidine $(30 \cdot 2 \mathrm{Ci} / \mathrm{m}$-mole) were purchased from the Radiochemical Centre, Amersham, Buckinghamshire. Carrier-free $\left[{ }^{32} \mathrm{P}\right]$ as orthophosphate (Io to $25 \mathrm{Ci} / \mathrm{mg}$.P) was purchased from the Australian Atomic Energy Commission, Lucas Heights, Sydney, N.S.W., Australia. 


\section{RESULTS}

$R N A$ and protein synthesis requirements during germination

The effect of proflavine on RNA and protein synthesis in Alternaria solani, Aspergillus nidulans, Neurospora crassa and Peronospora tabacina is shown in Fig. I. Addition of proflavine was followed, Io min. later, by either $\left[{ }^{3} \mathrm{H}\right]$ uridine or $\left[{ }^{14} \mathrm{C}\right]$-labelled amino

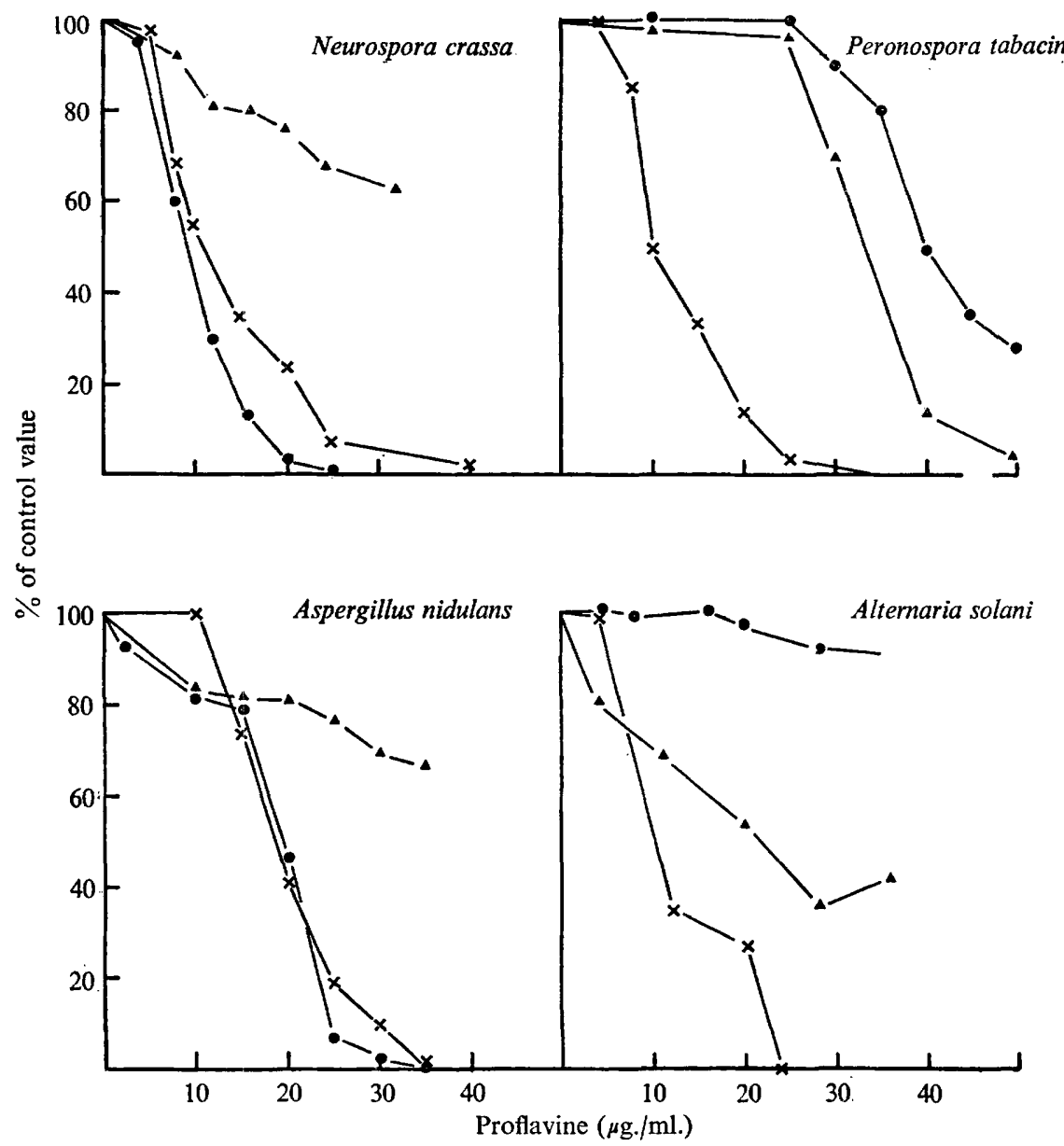

Fig. I. Effect of proflavine on RNA synthesis, protein synthesis, and germination in Peronospora tabacina, Neurospora crassa, Aspergillus nidulans, and Alternaria solani. For RNA and protein synthesis proflavine was added to conidia of $A$. solani and $P$. tabacina at the start of germination, and to $N$. crassa and $A$. nidulans conidia after 135 and $225 \mathrm{~min}$. incubation, respectively. In all cases, addition of proflavine was followed $10 \mathrm{~min}$. later by the addition of either $\left[{ }^{3} \mathrm{H}\right]$ uridine or $\left[{ }^{14} \mathrm{C}\right]$-labelled amino acids. Conidia were incubated in the presence of the isotope for I $5 \mathrm{~min}$., except for $A$. solani where uptake was for I $20 \mathrm{~min}$. Incorporation was stopped by adding $0.5 \mathrm{ml}$. cold $30 \%(\mathrm{w} / \mathrm{v}) \mathrm{TCA}$ and conidia were then treated as described previously (Hollomon, 1969). For germination proflavine was added to all conidia at the start of germination and the percentage germination was assessed after $4 \mathrm{~h}$. at $15^{\circ}$ for $P$.tabacina, $8 \mathrm{~h}$. at $30^{\circ}$ for $N$. crassa, $8 \mathrm{~h}$. at $37^{\circ}$ for $A$. nidulans, and $6 \mathrm{~h}$. at $26^{\circ}$ for $A$. solani. Results are presented as $\%$ of control where control represents the value obtained in the absence of proflavine. synthesis. 
acids. Uptake of these isotopes was stopped by adding $0.5 \mathrm{ml}$. cold $30 \%(\mathrm{w} / \mathrm{v})$ trichloracetic acid (TCA), and incorporation into TCA-insoluble material was taken as a measure of RNA and protein synthesis, respectively. As in other organisms (Waring, I966) proflavine inhibited RNA synthesis but reduced protein synthesis only at higher concentrations. Nevertheless, proflavine had a differential effect on germination (Fig. I). With $A$. nidulans and $N$. crassa inhibition of germination by proflavine closely

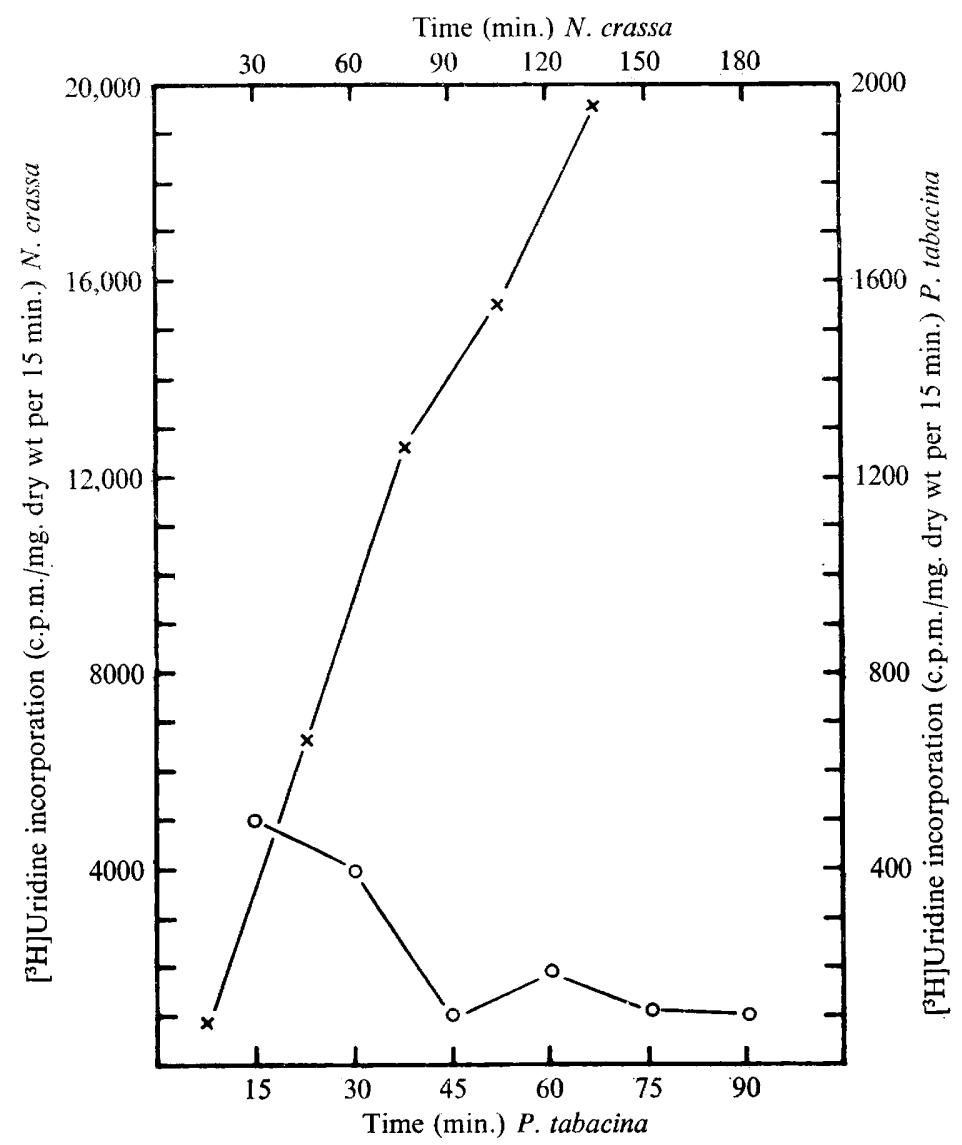

Fig. 2. The incorporation of $\left[{ }^{3} \mathrm{H}\right]$ uridine into RNA at intervals during germination. Neurospora crassa and Peronospora tabacina conidia were labelled for $15 \mathrm{~min}$. pulses with $0.4 \mu \mathrm{Ci} /$ $\mathrm{ml}$. $\left[{ }^{3} \mathrm{H}\right]$ uridine and $2 \cdot 0 \mu \mathrm{Ci} / \mathrm{ml}\left[{ }^{3} \mathrm{H}\right]$ uridine respectively. Incorporation was stopped by addition of $0.5 \mathrm{ml} .30 \%(\mathrm{w} / \mathrm{v})$ TCA and conidia were treated as described previously (Hollomon,

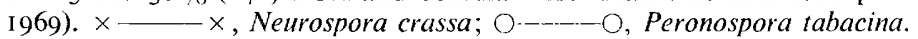

paralleled its effect on RNA synthesis. However, germination in $A$. solani and $P$. tabacina was unaffected by proflavine concentrations which severely inhibited RNA synthesis, but was inhibited at higher concentrations where proflavine inhibited protein synthesis. These results suggest that in $A$. solani and P. tabacina RNA synthesis is not required for germination, whereas in $A$. nidulans and $N$. crassa RNA synthesis is an essential requirement for germination. Similar experiments with Puccinia graminis were less satisfactory. Although uredospores germinated at pro- 

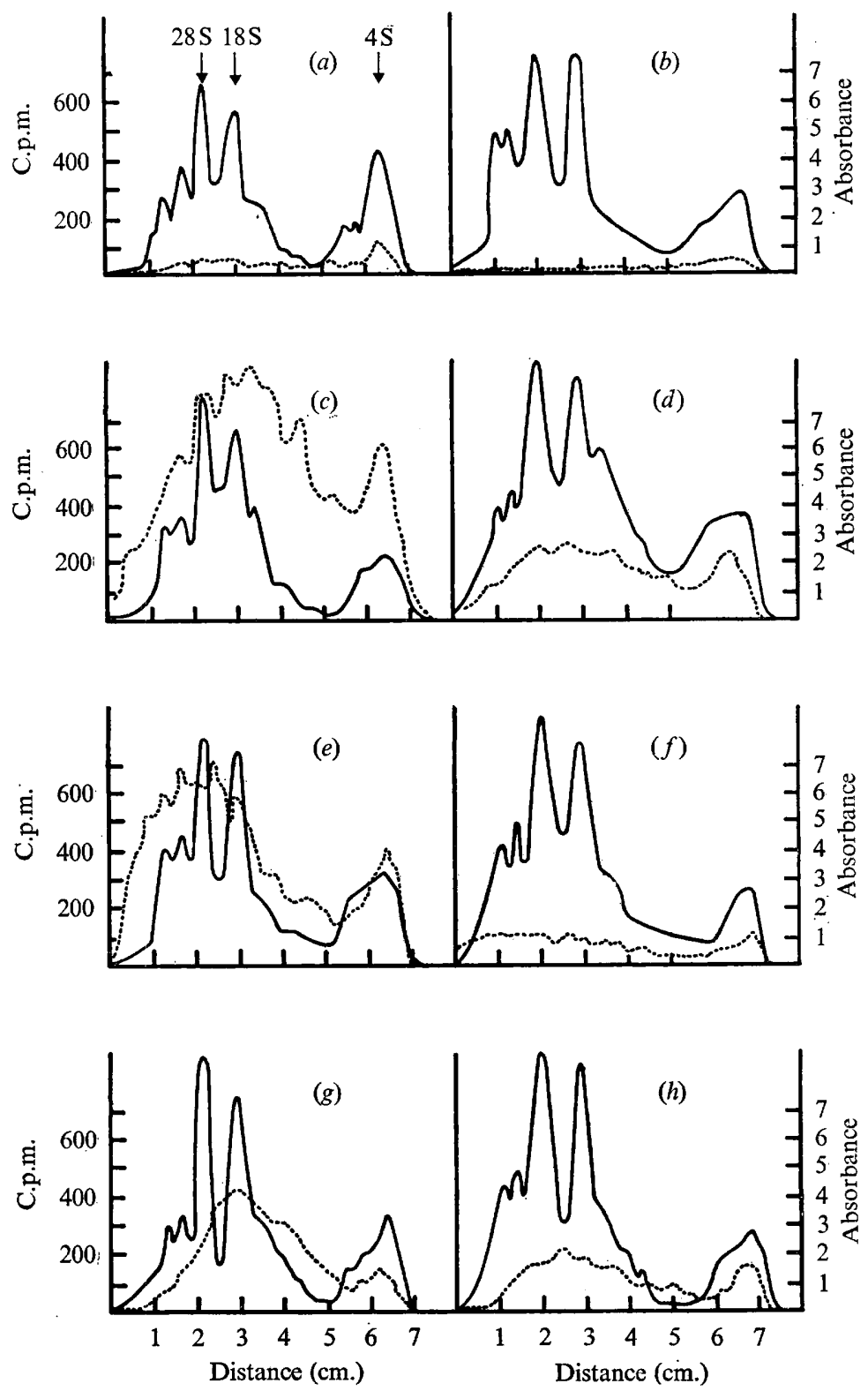

Fig. 3. RNA synthesis in germinating Peronospora tabacina conidia. For each treatment, $3.2 \times$ $10^{7}$ conidia were germinated in a medium without phosphate, in eight $15^{\circ} \mathrm{cm}$. diameter Petri dishes each containing a final volume of $20 \mathrm{ml}$. Conidia in one dish only were labelled for 20 min. with $\left[{ }^{32} \mathrm{P}\right](10$ to $1.2 \mu \mathrm{Ci} / \mathrm{ml}$.). After incorporation conidia from all dishes were collected together on a membrane filter either immediately or after a further $100 \mathrm{~min}$. incubation in the presence of excess non-radioactive phosphate (chase). RNA was extracted and fractionated as described in the methods section. $100 \mu \mathrm{g}$. RNA were applied to each gel. (a) 0 to $20 \mathrm{~min}$. pulse; $(b)$ o to 20 min. pulse, $100 \mathrm{~min}$. chase; $(c) 20$ to $40 \mathrm{~min}$. pulse; $(d) 20$ to $40 \mathrm{~min}$. pulse, I $00 \mathrm{~min}$. chase; $(e) 40$ to $60 \mathrm{~min}$. pulse; $(f) 40$ to $60 \mathrm{~min}$. pulse, Ioo min. chase; $(g) 60$ to $80 \mathrm{~min}$. pulse; $(h) 60$ to $80 \mathrm{~min}$. pulse, $100 \mathrm{~min}$. chase. - - , Counts $/ \mathrm{min} .\left[{ }^{32} \mathrm{P}\right]$; absorbance $620 \mathrm{~nm}$. (arbitrary scale). 
flavine concentrations which inhibited RNA synthesis in the other four species, uredospores failed to incorporate $\left[{ }^{3} \mathrm{H}\right]$ uridine into RNA before germ-tube emergence, and the effect of proflavine on RNA synthesis could not be determined.

It would seem, therefore, that differences exist between species in their requirement for RNA synthesis during germination. These differences were examined in greater detail using Peronospora tabacina and Neurospora crassa. To determine the rate of RNA synthesis prior to germ-tube emergence, conidia were labelled with $15 \mathrm{~min}$. pulses of $\left[{ }^{3} \mathrm{H}\right]$ uridine given at $15 \mathrm{~min}$. intervals for $P$. tabacina, and at $30 \mathrm{~min}$. intervals for $N$. crassa. Although initially low, the rate of incorporation of $\left[{ }^{3} \mathrm{H}\right]$ uridine into $N$. crassa increased as germination proceeded (Fig. 2). However, the rate of incorporation of $\left[{ }^{3} \mathrm{H}\right]$ uridine into $P$. tabacina conidia was not only much lower, but was fairly constant throughout.

\section{RNA synthesis in germinating Peronospora tabacina conidia}

Because of the low rate of incorporation, sufficient radioactivity could not be applied to gels to permit satisfactory resolution of RNA labelled during germination with $\left[{ }^{3} \mathrm{H}\right]$ uridine. This problem was overcome, however, by labelling with $\left[{ }^{32} \mathrm{P}\right]$ rather than

Table $\mathrm{I}$. Specific activity and RNAase susceptibility of $\left[{ }^{32} P\right]$-labelled $R N A$ from germinating Peronospora tabacina conidia

\begin{tabular}{|c|c|c|c|}
\hline \multirow{2}{*}{$\begin{array}{l}\text { Time after start of germination } \\
\text { at which }\left[{ }^{32}\right] \mathrm{P} \text { pulse was given } \\
\text { (min.) }\end{array}$} & \multicolumn{2}{|c|}{$\begin{array}{c}\text { Specific activity } \\
\text { (counts/min./mg.RNA) }\end{array}$} & \multirow{2}{*}{$\begin{array}{c}\text { Radioactivity remaining } \\
\text { after RNAase treatment } \\
\text { of pulse-labelled RNA } \\
(\%)\end{array}$} \\
\hline & Pulse & Chase & \\
\hline o to 20 & $0.49 \times 10^{5}$ & $0.36 \times 10^{5}$ & 28 \\
\hline 20 to 40 & $3.42 \times 10^{5}$ & $\mathrm{I} \cdot \mathrm{I} 2 \times 10^{5}$ & 8 \\
\hline 40 to 60 & $2 \cdot 2 \mathrm{I} \times 10^{5}$ & $1.25 \times 10^{5}$ & 7 \\
\hline 60 to 80 & $1.94 \times 10^{5}$ & $0.5 \mathrm{I} \times 10^{5}$ & 3 \\
\hline
\end{tabular}

$\left[{ }^{3} \mathrm{H}\right]$ uridine. Conidia were labelled with $20 \mathrm{~min}$. pulses of $\left[{ }^{32} \mathrm{P}\right]$ given at $20 \mathrm{~min}$. intervals during the first $80 \mathrm{~min}$. of germination. In some experiments, this pulse was followed by further incubation for $100 \mathrm{~min}$. in the presence of excess non-radioactive phosphate (chase). At the end of each pulse and each chase period, RNA was extracted with hot $\left(60^{\circ}\right)$ phenol to ensure extraction of the large molecular weight RNA. RNA was fractionated by polyacrylamide gel electrophoresis stained with Azure B and sectioned for radioactive counting. Any degradation occurring during extraction was monitored by the recovery of $\left[{ }^{3} \mathrm{H}\right]$-labelled Neurospora RNA which was added to the conidia at the time of grinding. Recovery of this labelled RNA varied between 60 and $80 \%$ of that initially added. Although some degradation undoubtedly occurred, this was similar in each preparation so that comparisons between preparations were possible.

Five major RNA bands were revealed when Peronospora tabacina extracts were stained with Azure B (Fig. 3): a fast-migrating soluble RNA band, two ribosomal RNA bands which were coincident with the ribosomal RNA bands of Neurospora crassa, and two bands migrating more slowly than ribosomal RNA. During the first 
180 min. of germination no changes in the position or intensity of any of these bands could be detected. Although a constant amount of RNA was extracted throughout the germination period, $\left[{ }^{32} \mathrm{P}\right]$ incorporation was not constant and was least during the first $20 \mathrm{~min}$. (Table I). Furthermore, $28 \%$ of this early $\left[{ }^{32} \mathrm{P}\right]$ incorporation was ribonuclease-resistant. After electrophoresis of this early RNA some radioactivity was detected in the anode buffer, suggesting incorporation into low molecular weight compounds, such as polyphosphate or simply $\left[{ }^{32} \mathrm{P}\right]$ orthophosphate carried through in RNA preparation.

Much of the $\left[{ }^{32} \mathrm{P}\right]$ incorporated into RNA early in germination was into soluble RNA (Fig. $3 a$ ). However, when germinated in the presence of ethidium bromide $(50 \mu \mathrm{g} . / \mathrm{ml}$.), an RNA synthesis inhibitor (Waring, 1966$), 20 \%$ of the $\left[{ }^{32} \mathrm{P}\right]$ incorpora-

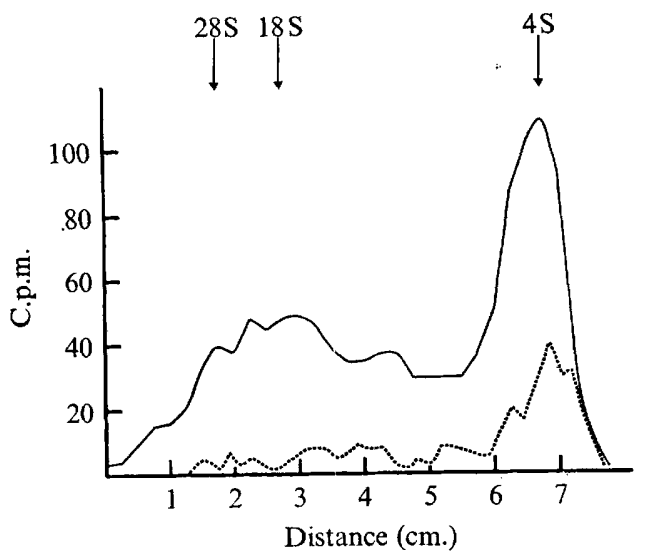

Fig. 4

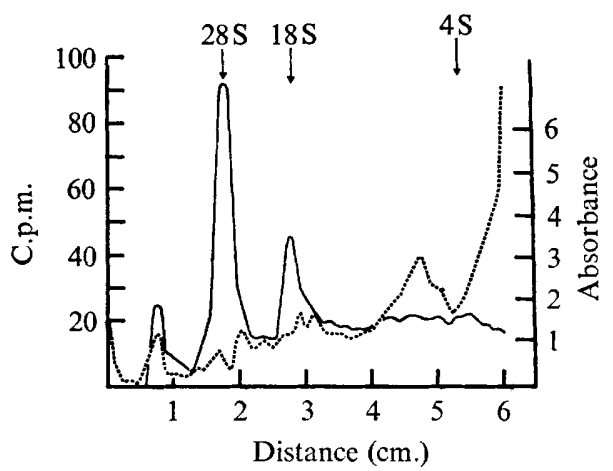

Fig. 5

Fig. 4. Effect of ethidium bromide $\left(50 \mu \mathrm{g} . / \mathrm{ml}\right.$.) on the incorporation of $\left[{ }^{32} \mathrm{P}\right]$ into RNA by germinating Peronospora tabacina conidia. $4.0 \times 10^{6}$ conidia were labelled with $\left.{ }^{32} \mathrm{P}\right]$ ( I I to $\mathrm{I} 2 \mu \mathrm{Ci} / \mathrm{ml}$.) during the first $20 \mathrm{~min}$. of germination. Uptake was stopped by rapidly cooling to $0^{\circ}$ and conidia were collected on a membrane filter together with $2 \cdot 8 \times 10^{7}$ ungerminated conidia. RNA was extracted and fractionated as described in the Methods section, and I $00 \mu \mathrm{g}$. RNA were applied to the gel. --_, Control; -- --, ethidium bromide.

Fig. 5. Polyacrylamide gel electrophoresis of RNA from ribosomes of germinating Peronospora tabacina conidia. Ribosomes were extracted from conidia germinated in the presence of $\left.{ }^{32} \mathrm{P}\right]$ as described in Table $3.265 \mu \mathrm{g}$. ribosomes were disrupted with $0.5 \%(\mathrm{w} / \mathrm{v})$ SDS and layered on to the gel and electrophoresed as described in the Methods section. - - - , Counts/min. $\left[{ }^{32} \mathrm{P}\right]$; ___

Table 2. The effect of ethidium bromide on $\left[{ }^{3} \mathrm{H}\right]$ cytidine and $\left[{ }^{3} \mathrm{H}\right]$ uridine incorporation into RNA in Peronospora tabacina

Conidia $\left(2.0 \times 10^{5} / \mathrm{ml}\right.$.) were incubated for $40 \mathrm{~min}$. in the presence of either $\left[{ }^{3} \mathrm{H}\right]$ cytidine $\left(2.0 \mu \mathrm{Ci} / \mathrm{ml}\right.$.) or $\left[{ }^{3} \mathrm{H}\right]$ uridine $(2.0 \mu \mathrm{Ci} / \mathrm{ml}$.). Incorporation was stopped by adding $0.5 \mathrm{ml}$ cold $30 \%(\mathrm{w} / \mathrm{v}) \mathrm{TCA}$, and conidia then treated as described by Hollomon (I969) except that the hot TCA wash was omitted.

Disintegration/min. incorporated into RNA

\section{Treatment}

Control

Ethidium bromide $(50 \mu \mathrm{g} . / \mathrm{ml}$.)

Inhibition by ethidium bromide $(\%)$ $\left[{ }^{3} \mathrm{H}\right]$ cytidine

$$
\begin{array}{r}
\text { I } 2,693 \\
9,9 \text { I } 3
\end{array}
$$$$
22
$$

$\left[{ }^{3} \mathrm{H}\right]$ uridine

$$
5,3 \mathrm{I} 4
$$$$
436
$$ 
ted into RNA during the first $20 \mathrm{~min}$. of germination remained, and was almost entirely in soluble RNA (Fig. 4). Whereas $\left[{ }^{3} \mathrm{H}\right]$ uridine incorporation early in germination was inhibited by ethidium bromide, much of the $\left[{ }^{3} \mathrm{H}\right]$ cytidine incorporation was not (Table 2). These results, together with the observation that much of the [ $\left.{ }^{32} \mathrm{P}\right]$ incorporated into soluble RNA was metabolically unstable and was lost during the chase incubation (Figs. $3 b, d$ ), strongly suggest that $\left[{ }^{32} \mathrm{P}\right]$ was incorporated into the three terminal nucleotides $(p \mathrm{C} p \mathrm{CpA})$ as well as into newly synthesized soluble RNA. In addition to soluble RNA, $\left.{ }^{32} \mathrm{P}\right]$ was also incorporated into heterodisperse RNA, although this was largely lost during the chase incubation (Fig. 3). Longer electrophoresis increased the separation of the ribosomal RNA bands without showing any particular association of these bands with radioactivity, which suggests that perhaps ribosomal RNA synthesis did not occur early in germination.

\section{Table 3. Incorporation of $\left[{ }^{32} P\right]$ into ribosomes during germination of Peronospora tabacina conidia}

Conidia $\left(8 \cdot 0 \times 10^{6}\right)$ were incubated for $60 \mathrm{~min}$. with carrier-free $\left[{ }^{32} \mathrm{P}\right](4.9 \mu \mathrm{Ci} / \mathrm{ml}$.) followed by a further $\mathrm{I} 00 \mathrm{~min}$. incubation in the presence of excess non-radioactive phosphate. Conidia were collected on a membrane filter and augmented with $4.0 \times 10^{7}$ ungerminated conidia. Ribosomes were isolated by the procedure already described.

\section{Fraction}

Total incorporated

$\times 10,000 \mathrm{~g}$ ppt. (mitochondria, nuclei)

$\times$ I I 7,000 $g$ supernatant fluid (soluble fraction)

$\times$ I $17,000 \mathrm{~g}$ ppt. (washed ribosomes)

Washed ribosomes after ppt. with $5 \%$ TCA

Washed ribosomes after dialysis against $0.05 \mathrm{M}$-tris $+\mathrm{HCl}$ $(\mathrm{pH} 7 \cdot 8)+0 \cdot$ I M-sodium EDTA
Counts/min. incorporated by $8.0 \times 10^{6}$ conidia

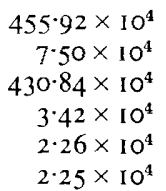

Conidia of Peronospora tabacina were incubated with $\left[{ }^{32} \mathrm{P}\right]$ during the first $60 \mathrm{~min}$. of germination followed by a further $100 \mathrm{~min}$. incubation in the presence of excess non-radioactive phosphate, thus reducing incorporation into metabolically unstable heterodisperse RNA. Ribosomes were then isolated and incorporation into the different fractions is given in Table 3 . Much of the $\left[{ }^{32} \mathrm{P}\right]$ incorporated by the conidia was contained in the soluble fraction obtained after centrifugation for $2 \mathrm{~h}$. at $117,000 \mathrm{~g}$, whereas little [ $\left.{ }^{32} \mathrm{P}\right]$ was incorporated into nuclei, mitochondria, or ribosomes. Further washing of the ribosomal pellet with KMT buffer did not remove radioactivity, yet only $66 \%$ of this incorporation into ribosomes could be precipitated with $5 \%(\mathrm{w} / \mathrm{v})$ TCA and was presumably RNA. Dialysis for $90 \mathrm{~min}$. against $0.05 \mathrm{M}$-tris $+\mathrm{HCl}$ $(\mathrm{pH} 7.8)$ containing $0.01 \mathrm{M}$-sodium EDTA resulted in a $34 \%$ loss of radioactivity from the ribosomes. When washed ribosomes were disrupted with $0.5 \%(\mathrm{w} / \mathrm{v})$ SDS and electrophoresed, no radioactivity was associated with ribosomal RNA, which confirms that no detectable ribosomal RNA synthesis occurred in P. tabacina during the first $60 \mathrm{~min}$. of germination (Fig. 5).

\section{$R N A$ synthesis in germinating Neurospora crassa conidia}

Neurospora crassa conidia readily incorporated $\left[{ }^{3} \mathrm{H}\right]$ uridine during germination (Fig. 2). As a result, conidia were labelled with $60 \mathrm{~min}$. pulses of $\left[{ }^{3} \mathrm{H}\right]$ uridine given at hourly intervals during the first $4 \mathrm{~h}$. of germination. Conidia were germinated with 
constant shaking at $30^{\circ}$ in flasks containing $20 \mathrm{ml}$. of medium. Following each pulse, RNA was extracted, fractionated by polyacrylamide gel electrophoresis, and stained with Azure B. As can be seen from Fig. 6 there was little evidence of degradation and four major RNA bands were detected: two ribosomal RNA bands (28S and I8S; Rifkin, Wood \& Luck, 1967); two fast-migrating bands, one being soluble RNA and
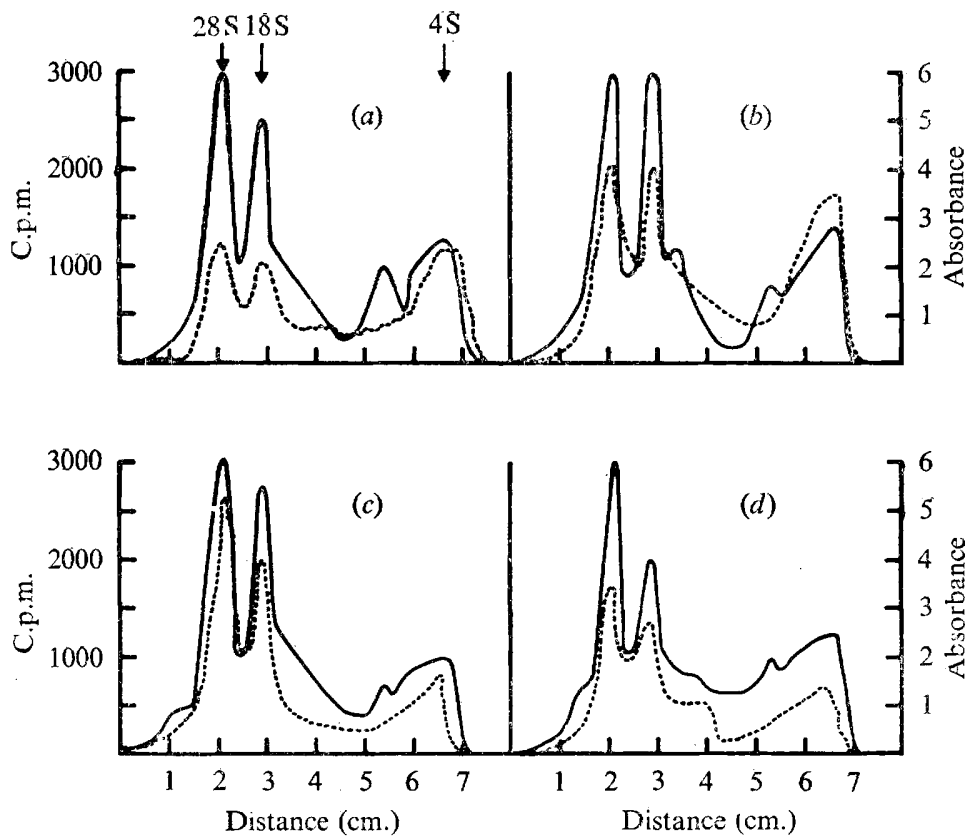

Fig. 6. RNA synthesis in germinating Neurospora crassa conidia. Conidia were germinated with constant shaking in five $500 \mathrm{ml}$. conical flasks each containing a final volume of $20 \mathrm{ml}$. Conidia were labelled for $60 \mathrm{~min}$. with $\left[{ }^{3} \mathrm{H}\right]$ uridine $(\mathrm{I} \cdot 25 \mu \mathrm{Ci} / \mathrm{ml}$. $)$ given at $60 \mathrm{~min}$. intervals after the start of germination. After incorporation conidia were collected together on membrane filters and RNA was extracted and fractionated. $23 \mu \mathrm{g}$. RNA were applied to each gel. (a) o to $60 \mathrm{~min}$.; (b) 60 to $120 \mathrm{~min}$.; (c) 120 to $180 \mathrm{~min}$.; (d) 180 to $240 \mathrm{~min}$.; - - - -, Counts/min. $\left[{ }^{3} \mathrm{H}\right] ;-—$, absorbance $620 \mathrm{~nm}$ (arbitrary scale).

Table 4. Specific activity of $\left[{ }^{3} \mathrm{H}\right]$ uridine labelled $\mathrm{RNA}$ from germinating Neurospora crassa conidia

Details of the conditions used to label conidia are given in Fig. 6

Time after start of germination at which

$\left[{ }^{3} \mathrm{H}\right]$ uridine was given (min.)

$$
\begin{aligned}
& \text { o to } 60 \\
& 60 \text { to } 120 \\
& 120 \text { to } 180 \\
& \text { I } 80 \text { to } 240
\end{aligned}
$$

Specific activity (counts/min./mg. RNA)

$$
\begin{aligned}
& 6.96 \times 10^{5} \\
& 7.26 \times 10^{5} \\
& 7.68 \times 10^{5} \\
& 7.44 \times 10^{5}
\end{aligned}
$$

the other perhaps 7 S RNA. As with Peronospora tabacina, changes in the position or intensity of these bands during germination were not detected. The total amount of RNA extracted increased as germination proceeded whereas the specific activity remained fairly constant (Table 4 ). At first $\left[{ }^{3} \mathrm{H}\right]$ uridine was incorporated equally into 
ribosomal and soluble RNA but, by the third hour, in contrast to the situation found in P. tabacina conidia, ribosomal RNA synthesis predominated.

\section{DISCUSSION}

Germination of spores used in these experiments was inhibited by actidione, an inhibitor of protein synthesis, indicating that protein synthesis was essential for germination (unpublished results). RNA synthesis, however, was not required for germination of Peronospora tabacina conidia (Hollomon, 1969), Alternaria solani conidia, and perhaps also Puccinia graminis uredospores. On the other hand, proflavine inhibited the germination of Neurospora crassa and Aspergillus nidulans conidia at concentrations which also inhibited RNA synthesis, suggesting that germination of these two species required the synthesis of RNA. Some fungal species seem, therefore, to differ in their requirements for RNA synthesis during germination.

Some RNA is, nevertheless, synthesized by germinating Peronospora tabacina conidia, and a comparison of this synthesis with the essential RNA synthesis in germinating Neurospora crassa conidia revealed further differences between the two organisms. Less $\left[{ }^{3} \mathrm{H}\right]$ uridine was incorporated into RNA by $P$. tabacina conidia than was incorporated by $N$. crassa conidia, despite a fivefold increase in the $\left[{ }^{3} \mathrm{H}\right]$ uridine concentration (Fig. 2). The RNA synthesized by $N$. crassa conidia was largely ribosomal with some soluble RNA (closely resembling the pattern of synthesis in germinating Aspergillus oryzae (Ono, Kimura \& Yanagita, I966; Tanaka, Ono \& Yanagita, 1966) whereas in P. tabacina ribosomal RNA synthesis was not detected. Instead, the RNA synthesized by $P$. tabacina at the start of germination was mainly soluble RNA, although some of this may represent the rapid end-labelling of the terminal $p C p C p A$ sequence. After the first $20 \mathrm{~min}$., but before germ-tube emergence, unstable heterodisperse RNA was synthesized in addition to the continuing synthesis of soluble RNA. Although this heterodisperse RNA may be messenger RNA, further work is required to confirm this. Early in germination a considerable proportion of the [ $\left.{ }^{32} \mathrm{P}\right]$ was incorporated into RNAase-resistant material which is, presumably, a low molecular weight compound such as polyphosphate or unincorporated [ $\left.{ }^{32} \mathrm{P}\right]$ orthophosphate.

During germination of both Peronospora tabacina and Neurospora crassa conidia changes in the position or intensity of the electrophoretically separated RNA bands were not detected; thus germination seemed to involve neither the appearance nor disappearance of RNA components. Although changes were not detected it is of interest to note, in view of the lack of ribosomal RNA synthesis in P. tabacina, two prominent bands which migrated more slowly than ribosomal RNA, and which were possibly precursor ribosomal RNA. Similar bands were barely detectable in $N$. crassa conidia where ribosomal RNA synthesis was more active.

Failure to synthesize ribosomal RNA is not unique to germinating Peronospora tabacina conidia. Ribosomal RNA synthesis does not occur in cleavage embryos of sea urchins (Nemer, 1963), amphibians (Brown \& Gurdon, I964), and echiuroid worms (Gould, 1969). As in germinating $P$. tabacina conidia, these systems are undergoing rapid development and, at least in sea urchins, this development also does not require the synthesis of new RNA (Spirin, 1966). Nevertheless, some RNA is synthesized by cleaving sea-urchin embryos (Wilt, 1964; Nemer \& Infante, I966), and the pattern of this synthesis is almost identical with that found in germinating $P$. tabacina 
conidia. Early in cleavage radioactivity is rapidly incorporated into soluble RNA and this incorporation is largely into the three terminal nucleotides $p \mathrm{C} p \mathrm{CpA}$ (Glisin \& Glisin, 1964; Gross, Kraemer \& Malkin, I965). In addition, there is also synthesis of heterodisperse messenger-like RNA (Wilt, 1964; Nemer \& Infante, 1966).

It is essential in a study of this type that RNA should be obtained with as little degradation as possible. Extraction of RNA with cold phenol + SDS from Peronospora tabacina conidia disrupted by ultrasonic treatment yielded degraded preparations. Undoubtedly some of this degradation was caused by the 20 min. ultrasonic treatment needed to disrupt the conidia and which has been shown to degrade Escherichia coli RNA (Das, Goldstein \& Lowney, 1967; Fry \& Artman, 1968). For this reason conidia were broken by grinding with solid $\mathrm{CO}_{2}$ and sand. Also, it is essential during germination to prevent the growth of bacteria which occur in P. tabacina conidial preparations. Fortunately, bacterial growth is inhibited by chloramphenicol (100 $\mu \mathrm{g}$. ml.) whereas germination is not. Failure to control bacterial contamination was responsible for the earlier report (Hollomon, 1969) of ribosomal RNA synthesis in $P$. tabacina conidia which conflicts with the results presented here.

Thanks are due to Miss J. Flanigan for her competent technical assistance. This work was supported by a grant from the Australian Tobacco Research Council.

\section{REFERENCES}

Bromfield, K.R. (I964). Cold-induced dormancy and its reversal in uredospores of Puccinia graminis var. tritici. Phytopathology 54, 68-73.

Brown, D. D. \& Gurdon, J. B. (1964). Absence of ribosomal RNA synthesis in the anucleolate mutant of Xenopus laevis. Proceedings of the National Academy of Sciences of the United States of America 51, I39-146.

Das, H. K., Goldstein, A. \& Lowney, L. I. (1967). Attachment of ribosomes to nascent messenger RNA in Escherichia coli. Journal of Molecular Biology 24, 23 I-245.

FRY, M. \& ARTMAN, M. ( 1968 ). Sedimentation behaviour of rapidly labelled RNA from Escherichia coli. Nature, London 217, 661-664.

Glisin, V. R. \& Glisin, M. V. (1964). Ribonucleic acid metabolism following fertilization in sea urchin eggs. Proceedings of the National Academy of Sciences of the United States of America 52, I $548-$ I 553 .

GotTlieb, D. (I966). In The Fungus Spore. Edited by M. F. Madelin. London: Butterworths.

Gould, M. C. ( 1969 ). A comparison of RNA and protein synthesis in fertilized and unfertilized eggs of Urechis caupo. Developmental Biology 19, 482-497.

Gross, P. R., Kraemer, K. \& Malkin, L. I. (1965). Base composition of RNA synthesized during cleavage of the sea urchin embryo. Biochemical and Biophysical Research Communications $\mathbf{1 8}$, $569-575$.

Hollomon, D. W. (1969). Biochemistry of germination in Peronospora tabacina (Adam) conidia: Evidence for the existence of stable messenger RNA. Journal of General Microbiology 55, 267-274.

LoENING, U. E. (1967). The fractionation of high molecular weight ribonucleic acid by polyacrylanidegel electrophoresis. Biochemical Jou:nal 102, 25 I-257.

LOENING, U. E. ( I 969). The determination of the molecular weight of ribonucleic acid by polacrylamide-gel electrophoresis. The effects of changes in conformation. Biochemical Journal II3, I3II38.

Lukens, R. J. (1963). Photo-inhibition of sporulation in Alternaria solani. American Journal of Botany 50, 720-724.

Nemer, M. (1963). Old and new RNA in the embryogenesis of the purple sea urchin. Proceedings of the National Academy of Sciences of the United States of America 50, 230-235. 
Nemer, M. \& INFANTE, A. A. (1966). Eariy control of gene expression. In The Control of Nuclear Activity. Edited by L. Goldstein. Englewood Cliffs, New Jersey: Prentice-Hall.

Ono, T., Kimura, K. \& Yanagita, T. (I966). Scquential synthesis of various molecular species of ribonucleic acid in the early phase of conidia germination in Aspergillus oryzae. Journal of General and Applied Microbiology, Tok yo 12, 13-26.

Peterman, M. L. (1964). In The Physical and Chemical Propertics of Ribosomes. Amsterdam: Elsevier.

RIFkIN, M. R., Wood, D. D. \& Luck, D. J. L. (1967). Ribosomal RNA and ribosomes from mitochondria of Neurospora crassa. Proceedings of the National Academy of Sciences of the United States of America 58, 1025-1032.

RYAN, F. J. (1950). Selected methods in Neurospora genetics. In Methods in Medical Research, vol. 3, p. 5I. Edited by R. Gerard. Chicago: Ycar Bwok Pubi.

SPIRIN, A.S. (1966). On 'masked' forms of mesienga: RNA in early embryogenesis and in other differentiating systems. Current Topics in Develo;inental Biology 1, 1-38.

Sussman, A. S. (1966). In The Fungus Spore. Edited by M. F. Madelin. London: Butterworths.

TANaka, K., ONo. T. \& Yanagita, T. ( 9966). Further obscrvations on the carocn dioxide incorporation into RNA in the early phase of conidia gcrinination in Aspergillus oryzae with special reference to soluble RNA synthesis. Journal of Generil anil Applied Microbiology, Tokyo 12, 329-336.

WARING, M. J. (1966). Cross-linking and intercaiatis in nucleic acids. Symposia of the Society for General Microbiology 16, 235-265.

WILT, F. H. (1964). Ribonucleic acid synthesis during sea urchin embryogenesis. Developmental Biology 9, 299-3r3. 